\section{ADORNED BODY, FEMALE LANGUAGE, AND EMOTIONAL MARRIAGE BETWEEN CHINESE WOMEN IN SNOW FLOWER AND THE SECRET FAN ${ }^{1}$}

\section{Pannawish Phasomsup ${ }^{2}$}

บทคัดย่อ

บทความวิจัยนี้มุ่งศึกษาสถานภาพทางสังคมและ กลวิธีเพื่อการอยู่รอดของสตรีจีนในสังคม ปิตาธิปไตยผ่านนวนิยายเรื่อง Snow Flower and the Secret Fan ซึ่งเป็นผลงานของนักเขียนสตรี อเมริกันเชื้อสายจีน Lisa See โดยผู้ประพันธ์ได้ เผยให้เห็นความเจ็บปวดที่สตรีจีนในยุคสังคมจารีต ได้รับจากประเพณีมัดเท้า นอกจากนี้ ผู้ประพันธ์ยัง แสดงให้เห็นถึงวิธีการเอาตัวรอดของตัวละครหญิง ในเรื่องจากสถานการณ์ดังกล่าวผ่านการเรียนรู้ ตัวอักษรหนี่ว์ซู ตัวอักษรที่เชื่อกันว่าผู้หญิงเป็นผู้ คิดค้นขึ้นเพื่อถ่ายทอดบอกเล่าความทุกข์และ อารมณ์ความรู้สึกภายในรวมถึงการสร้างมิตรภาพ ทางอารมณ์ระหว่างผู้ห ญิงด้วยกันที่เรียกว่า

1 เรือนกายที่ตกแต่ง ตัวอักษรสตรี และการแต่งงานทางอารมณ์ ระหว่างสตรีจีนในนวนิยายเรื่อง Snow Flower and the Secret Fan

2 (ปัณณวิชญ์ ผสมทรัพย์) English lecturer at Rajabhat University, Phuket.
'เหล่าถง' อันมีความสำคัญต่อการอยู่รอดภายใต้ อำนาจเพศชาย

หัวข้อของบทความวิจัยนี้แบ่งออกเป็น 4 หัวข้อย่อย ได้แก่ 1) ความเชื่อมโยงระหว่าง 'พื้นที่, กับ ‘สถานภาพสตรี, ซึ่งนำเสนอในรูปแบบคู่ตรงข้าม ระหว่าง 'พื้นที่สาธารณะ' กับ 'พื้นที่ส่วนตัว' 2) อักษรหนี่ว์ซูซึ่งเป็นตัวอักษรของผู้หญิงใช้เพื่อ ถ่ายทอดบอกเล่าอารมณ์ความรู้สึกข้างในและยัง เป็นเครื่องมือในการปลดปล่อยผู้หญิงออกจาก สังคมกระแสหลัก 3) แนวคิดว่าด้วย 'ร่างกายใน ฐานะพื้นที่ที่วาทกรรมเข้าไปจัดการอำนาจเกี่ยวกับ ความเป็นตัวตนของผู้หญิง' แนวคิดดังกล่าวถูก นำเสนอในรูปของประเพณีมัดเท้า 4) ความสัมพันธ์ แบบ 'เหล่าถง ' ซึ่งเป็นมิตรภาพทางอารมณ์ระหว่าง สตรีจีนโดยมองความสัมพันธ์ดังกล่าวในลักษณะ รักร่วมเพศและเป็นเครื่องมือที่เชื่อมร้อยผู้หญิงเข้า ด้วยกัน

\begin{abstract}
This research paper focuses on the study of Chinese women's social status and tactics for survival in a patriarchal society in Snow Flower and the Secret Fan written by Lisa See. The author reveals the agony of the foot-binding tradition Chinese women had to undergo in the feudal period. Lisa See also demonstrates how female characters survived such circumstances by means of learning Nü Shu, a woman's writing invented by women for women to express their
\end{abstract}


grievances and inner feelings, and of creating an emotional companionship between women called 'Laotong', which is significant for survival under the male dominance.

My discussion will be divided into five topics: 1) The linkage between 'space' and 'female status', which is presented in the form of the 'public-private' dichotomy. 2) 'Nü Shu', a woman language which is used to express inner feelings and as a tool for liberating themselves from the dominant culture. 3) The concept of the body as a site of discursive practice which exercises its power over female subjectivity. This concept is presented in the form of the foot-binding practice. 4) 'Laotong' relations or emotional companionship between Chinese women, which is viewed as a homoerotic relationship and as a tool for linking women together.

\section{Introduction}

The social status of Chinese women in the imperial period is one of the most discussed issues among feminists. It has long been depicted through the image of sexually oppressed and submissive victims of a patriarchal society. Obviously, most of them were dominated by the androcentric ideology or the so-called Three Obediences where a woman before marriage must identify her fate with that of her father, after marriage with that of her husband, and after the death of her husband with that of her son. (Li Yu-ning 2015: 78) These three obediences became an important precept that all Chinese women were required, inevitably, to comply with. This also linked Chinese women's lives to their role and male domination. In fact, this doctrine was intentionally devised in order to stabilize the family and reinforce male authority.

Since Chinese society was a patrilineal and patriarchal society under Confucianism that generally suppressed women, Chinese women were subordinated and expected to devote themselves principally to their husbands and families. They were not also allowed to express openly their own identity or feelings because expressing personal emotions was strongly proscribed for good Chinese women. However, in spite of sexual oppression and social inferiority, Chinese women sought to liberate themselves from such socio-cultural constraints in their own way.

Snow Flower and the Secret Fan is a work of biographical fiction written in 2005 by Lisa See, Chinese-American author, which portrays Chinese women's lives in the nineteenth century when girls suffered sexual repression and the foot-binding tradition. These miserable incidents are narrated by a female protagonist named 'Lily' who takes us on the life journey of a Chinese woman. Considering the protagonist's narrative, this novel can also be read as a confessional memoire of the guilt that Lily feels towards her beloved laotong.

In Snow Flower and the Secret Fan, I would like to point out four main topics which are tied to Chinese women's lives in the feudal period: 1) Space and Female Status, this topic is related to analyzing the link between gender and space. Based 
on the patriarchal perspective, the 'house' or the 'domestic sphere' is a space reserved for women and viewed as a private realm that assigns women such responsibilities as child-rearing, housekeeping and religious education. Lisa See starts her novel by describing the place in which the female characters live. Lily and other women are restricted to a place called 'women's chamber' where they are indoctrinated in The Women's Classic (See 2005:101) that extols submissive obedience and familial duty. This place is also an avenue for selfexpression and reflection of the self through embroidery and household chores. In the male view, such activities are considered inferior and worthless. However, when reading this novel using a feminist approach, readers can see that the female characters' domestic activities, in a metaphorical as well as literal sense, give rise to the productivity and creativity of many Chinese women in a 'domestic sphere'. 2) Nüshu Language, a woman's writing believed to be concocted by women for women to express their grievances and inner feelings. 3) Adorned Body through the foot-binding tradition, which is the beauty myth affecting Chinese women's bodies. Lisa See reveals that the fate of Chinese women in ancient times was tied to their small feet. Lily and other female characters unwillingly succumb this sexual oppression, believing that foot-binding is a testimony to submissive obedience. Despite being viewed as sexually oppressive, the foot-binding practice is regarded by female characters as a self disciplinary and collective experience. They learn to tolerate and come to terms with the bodily torment. However, all female characters in this novel believe that having small feet greatly increases their value for both their husband's family and their own, and finally 4) Laotong Relationship, an emotional companionship between Chinese women, which is viewed as a remedy for traumatic experiences. Also, Lisa See attempts to explain how Chinese women adapted themselves for survival and negotiated with the dominant patriarchy.

However, I would like to suggest to readers that all exquisitely detailed insights into women's lives in the seventeenth-to-nineteenth century China that Lisa See illustrates in her literary work can be viewed as a Western fantasy about the Ancient China or so-called Orientalism. Based on the Washington Post's review of Snow Flower and the Secret Fan: The wonder of this book is that it takes readers to a place at once foreign and familiar - foreign because of its time and setting, yet familiar because this landscape of love and sorrow is inhabited by us all. Snow Flower and the Secret Fan is a triumph on every level, a beautiful, heartbreaking story; it is important to notice that the use of two words 'foreign' and 'familiar' to describe this novel refers to the Western view of the East. According to Edward Said's notion that "Orientalism was the West's way of coming to terms with the East by defining the West as masculine, rational, and active, in contrast to the feminine, mystical, passive East." (Brownell and Wasserstrom 2002: 20) As a result, in the Western view, ancient China is a mysterious and enticing country whose 
women are engaged in sexual oppression and erotic fantasies, both of which draw much Western attention. This argument is similar to Chandra Mohanty's influential article "Under Western Eyes" where that image of "The Third Woman" is depicted as sexually repressed, tradition-bound and uneducated, in contrast to the educated, modern and autonomous first world women. (quoted in Felski 2000: 125) I here argue that when considering the context of Western society where the author lives, all images of Chinese women that Lisa See portrays in this novel might respond to Western curiosity and reinforce its superiority over China. The target readers that Lisa See wants to convey these images to are probably Western readers who are fascinated with the myth of the Orientalism.

\section{Space and Female Status: Creativity in the Domestic Sphere}

When reading literary works from the feminist perspective, readers should not take 'place' presented in the story for granted. Place/space is not only a scene/setting but also shapes characters' behavior, including the feelings and attitude characters have towards it; as John Archer says,

In terms of cognition and practice, built space thus plays an instrumental role in shaping categories of external relations by which people relate to each other, such as status and gender. In addition, built space plays an equally crucial role in shaping internal states of being and awareness - things such as feelings, sentiment, and effect. (2005:5)

Also, what John Archer mentions above corresponds with the concept of space in Chinese society. Similar to Western culture, the roles and duties of Chinese men and women were determined by making distinctions between the 'public sphere' and the 'private sphere', namely, the 'public sphere' is reserved for men, whereas women are restricted to only the 'private sphere'. It is noticeable that the public-private dichotomy is intimately connected to the sexual identity. As a result, Chinese females' roles and duties were intimately linked to such 'domestic' activities as child-caring, cooking and knitting, while those of the males were linked to such 'public' activities as politics or administration.

In Snow Flower and the Secret Fan, Lisa See reinforces this concept through Lily's account. Lily narrates that she and other women had to spend all their lives in a room called the 'women's chamber'. This chamber was also regarded as a forbidden place for men because male family members were not allowed to enter it. For Lily, the women's chamber is another world that excludes her completely from the masculine world. She knows only about what happens within this room. However, all female characters voluntarily embrace the Confucian precept that 'the domestic sphere is for women and the outside sphere is for men.' Whenever a woman transgresses 'the private sphere' either in her thoughts or in her actions, she 
will be stigmatized as a female villain or a threat to male domination.

I knew that men rarely entered the women's chamber; it was for us alone, where we could do our work and share our thoughts. I knew I would spend almost my entire life in a room like that. I also knew the difference between nei-the inner realm of the home-and wai-the outer realm of men-lay at the very heart of Confucian society. [...] Women should not pass beyond the inner chambers in their thoughts or in their actions. I also understood that two Confucian ideals ruled our lives. (See 2005:23-24)

Moreover, not only are Chinese females spatially restrained but they are also mentally proscribed in terms of not speaking of public matters, such as politics, that are reserved only for men, Whenever females attempt to express their opinions on politics, they are transgressing the socially-constructed borders and will be ordered to keep quiet, as shown in the dialogue between Lily and her husband.

When I returned home and asked my husband about the Taipings, he answered, "A wife should worry about her children and making her family happy. If your natal family disquiets you so, next time I will not give you permission to visit." I did not say another word about the outer realm. (See 2005:174)

Obviously, females or wives are strongly tied to domestic activities such as childcaring and looking after their families. They are not allowed to take part in male matters because of the belief that females interfering in politics cause the collapse of the state. (Mann 2014: 15) According to Neo-Confucian paradigms, men are linked to rationality that is relevant to politics whereas women are linked to emotion and sexuality. (Rabaté 2003: 231)

In Snow Flower and the Secret Fan, readers also perceive how inferior Chinese women were. Lily narrates that the room where she and other women live is so crowded and they have to share the room with animals: "The rest of our rooms were small, our floor was hard-packed earth, and, as I said, our animals lived with us." (See 2005:10) I here argue that the above depiction of Lily's room reflects Chinese women's inferiority and gender discrimination. It could be said that they were treated as if they were 'domestic animals'.

Furthermore, the sentiment of the characters that dwell in the women's chamber reflects sexual oppression in the spatial context. Lily describes her gloomy feelings at having to restrain herself in the women's chamber and longs for her lost freedom.

[..] and I still remember the feel of the mud between my toes, the rush of water over my feet, the cold against my skin. Beautiful Moon 
and I were free in a way that we would never be again. But I remember something else very distinctly from that day. From the second I woke up, I had seen my family in new ways and they had filled me with strange emotionsmelancholy, sadness, jealousy, and a sense of injustice about many things that suddenly seemed unfair. I let the water wash all that away." (See 2005: 15)

Lily longs for her lost joyful memories in childhood before having her feet bound. Although Lily learns a lot of things necessary to her marriage, for her, this women's chamber is a place of secrets, suffering and mourning because she witnesses the demise of her third Sister that takes place within this room. However, Lily's feeling of melancholy disappears once she knows Snow Flower, her laotong, who brings Lily's happiness back: "She could be in that room-which I saw as a place of secrets, suffering, and mourningand turn it into an oasis of bright times, good cheer, and silly fun." (See 2005: 62( Snow Flower, therefore, becomes a persona who then influences Lily's life.

Having to be confined within the domestic area, the female characters learn to redefine their dwellings as 'a place of creativity and learning' in order to survive sexual repression. Lily narrates that from morning to afternoon, the female family members: Mama, Elder Sister and Aunt, always come to teach her how to do artistic activities and give her the study of Nü Shu. For her, these help to soothe her agony from foot-binding and being kept in strict isolation within the women's chamber.

In the early morning hours, the two of us - under Elder Sister's supervision-practiced new stitches. In the late morning, Mama taught me how to spin cotton; in the early afternoon, we switched to weaving. Beautiful Moon and her mother did the same lessons only in reverse. Late afternoons were devoted to the study of $n u$ shu, with Aunt teaching us simple words with patience and great humor. (See 2005: 36)

Even though, from a masculine point of view, these artistic activities are inferior and insignificant compared to those done by males, such as politics and outdoor activities, for many women, they are viewed as a venue for expressing female creativity and skills through daily activities. We can see this from Lily's account of her shoemaking that allows her to express her artistic skills.

Shoemaking allowed us to display our technical as well as our artistic skills, but it also sent a joyful and optimistic message. In our dialect, the word for shoe sounds the same as the word for child. (See 2005: 90)

The domestic activities that women do at home can be viewed as 'adaptation for survival'. For women are intricately related to the productive role and most of their activities, for instance, child-bearing 
or food-preparation, contribute to the family's life and survival. Thus, they need to learn to adapt what they have for utility and the survival of their family members. The female characters in Snow Flower and the Secret Fan are a good example of this. When Snow Flower's family becomes impoverished, she needs to learn to survive abject poverty by reshaping her cloth to a new dress for her marriage.

They had taken cloth that had once been sent from Snow Flower's family to Snow Flower's mother as a brideprice gift, been shaped into the dowry of a fine maiden, been reshaped again into clothes for a beautiful daughter, and now restructured another time to announce the qualities of a young woman marrying into the house of a polluted butcher. All of it was women's workthe very work that men think is merely decorative - and it was being used to change the lives of the women themselves.

(See 2005: 127)

Since most Chinese women were illiterate and supposed not to show explicitly their thoughts, inner feelings, and identity, embroidery became a tool by which Chinese females used to communicate secretly among themselves. They, therefore, learned tactics to convey their desires by means of knitting or embroidery as the female characters in Snow Flower and the Secret Fan do.
Beautiful Moon's stitches were concentrated on her red wedding slippers, the most precious of all shoes. Pink and white lotus flowers bloomed, symbolizing her purity and fruitfulness. [...] (Snow Flower) had simply moved on to a pair for herself, which employed purple silk trimmed with white. When the characters for purple and white were written together they meant a lot of children. (See 2005:92)

The above description corresponds with what Shelley Phillips has argued on the significance and implications of embroidery, Shelley says "[...] embroidery was utilized as a means of self-expression and private communication. Mother and daughters expressed their resistance as well as resignation to patriarchal culture through the content of their embroidery." (quoted in Abudi 2011:117)

Apparently, apart from written language that is reserved only for males, pictures or symbolism presented in their work is also viewed as hidden messages in which women can express their thoughts and unspoken feelings. Additionally, embroidery is an activity that inextricably links women to domestic roles and tasks, in accordance with the public-private dichotomy. Lisa See wants to demonstrate that living under dominant norms and the patriarchal society compelled women to adapt for survival and seek to free themselves from social constraints in the form of such activities, which were a 
platform for silently expressing creativity, identity and personal experiences.

\section{Nü Shu: Women's Writing as a Tool to Overcome Patriarchy}

Since women in ancient China were not allowed by the rigid constraints of Confucian sexual and social mores to speak of their inner feelings, they struggled to get their voices to be heard and break the silence they encountered. In fact, not only did women's silence involve not being allowed by the dominant culture to tell about their feelings and traumatic experiences but it is also related to the fact that who listened to and understood their stories. Such sexual subordination facing Chinese women is viewed as 'collective experiences', which only women afflicted by the same misfortune can comprehend. As a result, expressing one's sentiments or bitter experiences is represented in various forms. As discussed in the previous section, the laotong relationship is a form of remedy that frees them from emotional repression.

Moreover, telling one's experiences and sentiments in a form of writing is another remedy. In The Laugh of the Medusa, Cixous (1981) asserted the importance of female writing that "Woman must write herself, must write about women and bring women to writing, from which they have been driven away as violently as from their bodies." (quoted in Warhol and Herndl 1997: 15) Cixous also advocated that, in writing, women should create their own language to serve as a form of celebration of all aspects of femininity. Likewise, in This sex which is not one,
Irigaray (1985) also argued that women 'find themselves reduced to silence in terms of a culture that does not allow them to be expressed'(quoted in Warhol and Herndl 1997:136), thus, they should create a communication system to enable them to break the silence. It is the form of expressing women's desires and identity through a language invented by women that I want to explore in this section.

In ancient China, few Chinese women gained educational opportunity by learning official Chinese characters, which were mostly reserved for men. Considered from the view of the patriarchy, female literacy was considered as a superfluity and a threat to male dominance. As a result, Chinese women were left illiterate. Many of them had to suffer ignorance of how to express their pain. Some of them resorted to embroidery as a means of telling their bitter stories as discussed in the issue above. In Jiangyong Country, Hunan Province, southern China, women were able to learn a form of writing called 'nüshu', which means 'women's script'. $N \ddot{u} s h u$ is believed to have been concocted by women to form a kinship and social bonds that defied the patriarchal society in which they lived. Although women were kept away from a knowledge of official Chinese characters, they were granted access to 'female writing', which gave them a sense of power to assert their identity. (Lee 2002:101- 107)

For Chinese women suffering sexual oppression in a patriarchal society, Nü Shu is a tool for liberating themselves from sexual inequality; as Lily narrates, "My only rebellion came in the form of $N \ddot{u} S h u$, 
our women's secret writing." (See 2005:4) With the use of this language, Lily can express her feelings regardless of social roles and constraints. She can create a sphere for herself to construct her true identity.

My first break with tradition came when Snow Flower-my laotong, my "old same," my secret-writing partner - sent me the fan that sits here on my table, and then again after I met her. But apart from who I was with Snow Flower, I was resolved to be an honorable wife, a praiseworthy daughter-inlaw, and a scrupulous mother. (See 2005:4)

$N u ̈ S h u$ is also renowned as a 'mysterious form of writing' that allowed women to construct a female world protected from male invasion. In Snow Flower and the Secret Fan, Lily's aunt-in-law tells her and Snow Flower about the history of this language. It was firstly invented in Song times by a lonely concubine named Yuxiu who wanted to send a message to her natal family. Yuxiu was kept in the palace without any way of communicating with her mother and sisters. If she wrote an incautious word in her message to her family, it could result in decapitation. Yuxiu eventually created entirely new characters that had nothing to do with men's writing to avoid being read by others. Yuxiu's invention of language reflects woman's tactics for negotiating with male dominance.

Learning $N \ddot{u} S h u$ is ordinarily practiced within the women's chamber - the realm that is viewed as 'a sacred sphere' for only women. To understand any messages written in Nü Shu it is chiefly based on phonetics, context and inference rather than the concrete characters of official Chinese. These rules reflect women's ability at self-adaptation for survival. With the ambivalence of meaning in the Nü Shu language, women are able to openly express themselves and their desires safe from men's prying eyes. This is the reason why Nü Shu is considered as a 'sacred and cryptic' language and why it is obligatory that its existence be kept from men's perception and transgression; as Lily's aunt-in-law says "But the two most important rules are these: Men must never know that it exists, and men must not touch it in any form." (See 2005:25)

Furthermore, $N \ddot{u} S h u$ is used as a tool for recording women's collective memories, which are mainly overlooked by mainstream narratives. From the androcentric view, female stories are considered to be inferior and unimportant when compared to male ones. Importantly, women as well as their sentiments are excluded from the writing of history that requires only the exercise of reason, which is linked to masculinity. As a result, Nü Shu might be the only language in China that gives Chinese women the chance to produce records of their own stories, which define positive terms for themselves in the contexts in which they live. Their records of stories are also quietly passed down from woman to woman or from generation to generation. Lily demonstrates the crucial roles that $N \ddot{u} S h u$ plays: 
These last years I have copied down many autobiographies for women who never learned nu shu. I have listened to every sadness and complaint, every injustice and tragedy. I have chronicled the miserable lives of the poorly fated. I have heard it all and written it all down. But if I know much about women's stories, then I know almost nothing about men's, except that they usually involve a farmer fighting against the elements, a soldier in battle, or a lone man on an interior quest. (See 2005:5)

What Lily describes above also reflects the failure of official Chinese - a maledominated language - to understand and recognize women's existence and emotions. Obviously, Lily is criticizing the process of Chinese historiography that overlooks an aspect of women's emotions. It is noticeable that Chinese historical narratives chiefly depict men's heroic deeds and great stories. Such a failure is asserted in Cixous's view towards the power of writing by women or so-called 'L'écriture féminine'; "It is by writing, from and toward women, and by taking up the challenge of speech which has been governed by the phallus, that women will confirm women in a place other than that which is reserved in and by the symbolic, that is, in a place other than silence." (quoted in Warhol and Herndl 1997:351) Therefore, the accounts written in women's language for communicating with women are considered as 'herstory'

\footnotetext{
${ }^{3}$ This word is invented to emphasize the role
} of women in writing history or history being
In Snow Flower and the Secret Fan, Lisa See accentuates the significance of Nü Shu as a lieu de mémoires between Lily and Snow Flower. The relationship between the two female characters takes place through exchanging messages written in $N u ̈ S h u$ on a fan. Lisa See wants readers to perceive the feelings of these two characters when they are facing hardship and isolation, especially when Snow Flower writes to Lily about the loss of her daughter. See opts to describe the character's sorrow in the form of a letter written in N $\ddot{u} S h u$ because the death of the daughter is her guilt. Snow Flower unwillingly endures grievances and condemnation from both her husband and mother-in-law. Not one of her family members understands her sufferings but expects her to have a son. In the letter, Flower tells Lily about her wish to escape from a painful loss. She cannot live any longer with this grief. What happened to Snow Flower cannot be depicted in any other form of narrative only in Nü Shu.

My daughter was born dead. She left without planting roots, so she knew nothing of the sorrows of life. [...] Everyone in my household blames me. My mother-in-law says, "Why did we marry you in if not to bear sons?" My husband says, "You are young. You will have more children. Next time you will bring me a son." I have no way to vent

told from a woman's point of view. It is used as a pun on the word 'history', which is believed to be written from the masculine view of point. See more in Keith Jenkins, The Postmodern History Reader. (1997). London, New York: Routledge. 
my sorrow. I have no one to listen to me. I wish I could hear you coming up the stairs. I imagine myself as a bird. I would soar in the clouds, and the world below would seem very far away. (See 2005:166)

Nevertheless, this language is like a twoedged sword because of the fact that its meaning depends on the context and the reader's interpretation, as in aunt-in-law's warning that "Every word must be placed in context. [...] Much tragedy could result from a wrong reading." (See 2005, p.69) In the end, aunt-in-law's warning comes true when Lily misreads the message written by Snow Flower. Lily mistakenly thinks that Snow Flower has betrayed her trust by sharing her secrets with other women. Her misunderstanding leads to the tragedy when Lily decides to break up with Snow Flower. For this issue, I would like to argue Lily's misunderstanding resulting from her lack of feminine reading which pays attention to texture, context and shades of meaning. It is possible that after her marriage, Lily might be dominated by the masculine viewpoint, especially the heterosexual relationship with her husband, which suppresses the skill of reading such elements. Such a failure can be noticed from Plum Blossom's conclusion, "But you had too much man-thinking in you. You loved her as a man would, valuing her only for following men's rules." (See 2005:243) When Lily read Snow Flower's message in the same way as men did, she didn't comprehend what Snow Flower actually wanted to express. Therefore, it can be concluded that Lily's mistake reflects the failure of men to understand and interpret what women want to convey.

\section{Foot-binding: Body as a Site of Discursive Practice}

From a sociological perspective, the body is not simply a biological entity but also bears the mark of cultural inscription. It becomes a site where different discourses and power exercise, just as in Foucault's view that the "body is the field of inscription of socio-symbolic codes." (as cited in McLaren 2002: 92) Likewise, postmodern feminists stretch Foucault's idea about a body as a site of social control to account for women's experience.

The foot-binding tradition was a pattern of the beauty myth which overtly reinforces patriarchal ideology. It illustrates how cultural norms operate on the feminine body in insidious ways, through various disciplines and practices. Importantly, this tradition was used as a tool for subjugating women to male dominance. It rendered women as sex objects to gratify men's erotic fantasies because women's small feet like 'little lotus' were thought to be highly attractive and arouse sexual desire. Also, once having their feet bound, Chinese women were limited to immobility and kept only in a subservient domestic state. Indeed, foot-binding was invented to reinforce the 'public' and 'private' dichotomy.

In her article "The Body as Attire: The Shifting Meanings of Foot binding in Seventeenth-Century China", Dorothy Ko (1997) argued that besides being condemned as a most dreadful bodily 
mutilation inflicted on women's bodies, foot-binding was also regarded as a sign of Han Chinese civility and superiority and then employed to distinguish Han females from barbarians:" Besides functioning as a marker of national boundaries, footbinding was also signaled femininity and hence gender distinctions, as is often argued." (1997:17)

Moreover, Ko claims that properly clothed and adorned bodies, according to Confucianism, differentiated human beings from savagery or bestiality due to the belief that elaborate attire was the significant expression of civility, culture and humanity. As for Han Chinese women, it was believed that "foot-binding was considered part of female attire, an adornment to be exact, not a form of bodily mutilation. It was supposed to embellish, adding something to the female body." (Ko 1997: 33) This was the reason why Chinese females in feudal times were required to have their feet bound as a sign of high cultural prestige and gender identity, which is relevant to what Lisa See says, "In cities, girls who come from the gentry class have their feet bound as early as age three. [...]The poorest girls don't have their feet bound at all." (See 2005:17) Obviously, the body is not only related to the 'physical' aspect but also becomes the terrain on which the ethnic and cultural boundaries between the civilized Han Chinese and the barbaric "Other" were drawn. (Ko 1997: 10)

In Snow Flower and the Secret Fan, the author focuses on the sexual repression inflicted on women's bodies in the form of foot-binding. The agony and violence caused by the foot-binding practice is chiefly presented in the female characters' narrative of childhood. Lisa See wants to point out to the readers that the footbinding practice was most necessary for Chinese women in the feudal period because the tiny narrow size of bound feet, called 'lotus feet', was a symbol of beauty and a sign that a woman would be a good wife and subservient to her husband.

We can see the link between the body, in particular the female body, and social status in Snow Flower and the Secret Fan. Lily describes how she has to unwillingly endure the agony of foot-binding, believing this will be one of the main avenues for her to find a good husband and to be socially acknowledged; as Lily says

My small feet would be offered as proof to my prospective in-laws of my personal discipline and my ability to endure the pain of childbirth, as well as whatever misfortunes might lie ahead. My small feet would show the world my obedience to my natal family, particularly to my mother, which would also make a good impression on my future motherin-law." (See 2005: 34)

Lily's claim is pertinent to Bourdieu's conceptualization of the body as a bearer of value. This concept identifies the interrelationship between social location and corporeal development. Bourdieu (1984) views body as a carrier of symbolic value, which has become a form of commoditized 'physical capital'. 
Moreover, Shilling (1993) developed Bourdieu's concept more broadly through his theory of body, in which he argued that physical capital encompasses the symbolic value of the exterior surface of the body in terms of shape, weight, physique and looks. (quoted in Lisa Hunter, Smith and Emerald 2015:14) This concept can be seen as relevant to Chinese women's footbinding practice which is a crucial component in the construction of social difference in terms of gender, status and ethnicity as mentioned above. The footbinding practice is also viewed as a tool to valorize a woman's body. Bound feet act as displays of 'physical capital', which indicates the 'virtuous' and the 'marriageable'; as Lily says, "All I knew was that footbinding would make me more marriageable and therefore bring me closer to the greatest love and greatest joy in a woman's life — a son." (See 2005:25) Thus, foot-binding became a mechanism for recruiting women with 'physical capital' into production and reproduction by bearing sons.

In the chapter "Food-binding", the author explains that Chinese girls normally started the process of foot-binding at the age of six, whereas Lily is an exception because a village diviner notices special features on herself which are believed to bring good luck to her family. So, he asks her parents to postpone the process until she turns seven years old. The village diviner's foretelling reflects Chinese women's fate that is influenced by male discourse as well as the beauty myth.

"Your daughter presents us with a special circumstance," he said. "I saw something in her yesterday, and Madame Wang, who brings additional expertise, agrees. Your daughter's face is long and slender like a rice seed. Her full earlobes tell us she is generous in spirit. But most important are her feet. Her arch is very high but not yet fully developed. This means, Mother, that you should wait one more year to begin foot binding." (See 2005:20)

Lily also explains that the girls of the gentry class in the city normally have their feet bound when they become three while those of the poorest family are excepted, ending up with being sold as servants or becoming "little daughters-in-law". These girls with unbound feet are usually treated as inferior and as mere sexual objects for bearing children. The significance of footbinding is also highlighted by Lily's mother. She tries to persuade Lily to endure the pain of the foot-binding procedure for her better future. In Chinese patriarchy, the submission to suffering is one of the most preferred virtues that Chinese women at such a period were required to possess. Consequently, enduring the agony of the foot-binding practice represents the ideally virtuous female.

"A true lady lets no ugliness into her life," she repeated again and again, drilling the words into me. "Only through pain will you have beauty. Only through suffering will you find peace. I wrap, I bind, but you will have the reward. (See 2005:30) 
Eventually, Lily manages to regard her sufferings from foot-binding as an adaptation or learning for survival in the patriarchal society. She realizes her sisters' future as well as hers depends on how much they can endure this corporal anguish.

Although foot-binding is regarded as a form of sexual oppression, Chinese women in the old times willingly succumbed to this brutal myth and learned survival tactics. This is what Lisa See wants to display. According to Michel de Certeau's view, the weak or powerless struggle to survive within situations of oppression, deploying tactics: the means of fighting back in responsive and flexible ways. De Certeau also argues that "tactical deviations are inventive and creative actions. Smart adaptation and appropriations are tactics used by the agents to survive in their own way" (quoted in Highmore 2002: 93) Therefore, Chinese women sought to adapt themselves for survival by creating useful hints for alleviating the pain of their bound feet or else they helped one another in the foot-binding practice; as Lily describes:

On the fourth day, we soaked our bandaged feet in a bucket of hot water. The bindings were then removed, and Mama and Aunt checked our toenails, shaved calluses, scrubbed away dead skin, dabbed on more alum and perfume to disguise the odor of our putrefying flesh, and wrapped new clean bindings, even tighter this time. Every day the same. Every fourth day the same. Every two weeks a new pair of shoes, each pair smaller. The neighbor women visited, bringing us redbean dumplings, in hopes that our bones would soften faster, or dried chili peppers, in hopes that our feet would adopt that slim and pointed shape. Elder Sister's sworn sisters arrived with little gifts that had helped them during their foot-binding. (See 2005: 29)

It seems that despite being unable to avoid the bodily torment, the female characters learned to survive and came to terms with their inferior status. I would like to argue that the foot-binding practice can be viewed as a 'self-disciplinary' and 'collective experience' among women. This practice implicitly encourages girls to be more disciplinary about their bodies by caring for bound feet and this also acts as a liaison between young girls and the elderly; a sharing of fate. In Snow Flower and the Secret Fan, Lily learns from the pain of foot-binding what the three of them will be like in the future.

But we learned the most important lesson for all women: that we must obey for our own good. Even in those early weeks, a picture began to form of what the three of us would be like as women. Beautiful Moon would be stoic and beautiful in all circumstances. Third Sister would be a complaining wife, bitter about her lot, ungracious about the gifts that were given to her. As for me-the so-called special one- 
MANUSYA: Journal of Humanities Regular 21.2, 2018

I accepted my fate without argument. (See 2005: 29-30)

Moreover, Chinese women are not only victimized as sexual objects but they also avail of their inferior status to negotiate with male dominance. In Snow Flower and the Secret Fan, Lily learns to make use of her bound feet as a tool for manipulating her husband's erotic fantasies. She reveals that her small feet never diminish her husband's sexual desire when they are together in bed.

[...] my feet would be something that would hold my husband's fascination during the most private and intimate moments between a man and a woman. His desire to see them and hold them in his hands never diminished during our lives together, not even after I had five children, not even after the rest of my body was no longer an enticement to do bed business. (See 2005:34)

This description reflects the shifting role and status of a woman, from the role of a sexual object to that of a sexual agent. Despite becoming more aged and lacking in any enticement, Lily manages to use her small feet to seize her husband's sexual desire. Lily's small feet are viewed as a fetish that has a powerful allure and they become an agent to whom the fetishist is bound out of desire. This erotic fascination caused by the beauty myth of foot-binding is not far from the notion of the 'femme fatale', which describes the beauty of an evil woman luring men to their death. It can be concluded that although Chinese women in ancient times submitted to bodily mutilation in the form of the footbinding practice, believing this custom figured as a symbol of the 'civilized body' and 'virtuous women', they didn't act as 'passive victims' but learned to come to terms with it and attempted to exploit their bodies to negotiate with the patriarchy.

\section{Laotong: Eternal Friendship and Emotional Marriage between Chinese Women}

Lily, the female protagonist, knows another relationship other than that of her family members - that is 'laotong', which plays a crucial role in her later life. 'laotong' (literally, 'old same') is a type of emotional bond between Chinese women, which was practiced in Hunan. It is ascribed to the minority Yao rather than the majority ethnic group of Han. In China, there are two types of soul friendship among women: sworn sisters and laotong. Both of these friendships are the recognition of the significance of women's supportive affairs, which helps them endure hardship throughout their lives. (Davis, 2009:4) However, for Chinese women, the laotong was the strongest and most precious bond of their lives. This was a more singular and sacred relationship between two women. The Laotong relationship is definitely different from 'sworn sisterhood' because it is a match of two girls who match astrological profiles with each other and is practiced with the purpose of emotional companionship and eternal fidelity. The two girls as laotongs will continue to keep in contact for the rest of their lives while 'sworn sisterhood' will dissolve once both 
girls marry out to other villages. Lily defines this relation in Snow Flower and the Secret Fan,

I knew the words and what they meant. A laotong relationship was completely different from a sworn sisterhood. It involved two girls from different villages and lasted their entire lives, while a sworn sisterhood was made up of several girls and dissolved at marriage. (See 2005: 22)

In addition, the laotong relationship is viewed as an 'emotional marriage', which is different from the 'marriage between men and women'. In ancient Chinese times, men and women could sometimes marry each other regardless of passion or love because marriage was regarded as a commercial transaction instead of a match of love. Also, they were customarily married with the mere purpose of bearing children or successors, especially boys. Some couples could live together without passion or love whereas a laotong was a woman's emotional partner who played a crucial role in a woman's life and helped her through painful experiences. The women who became laotongs were required to be faithful to each other until both died. They couldn't betray their own laotong sharing their love or secrets with others. Violating such a taboo meant breaking up their eternal friendship, which was extremely unacceptable; as Lily says when disappointed with Snow Flower's betrayal

That she seemed to be abandoning our promises in favor of a new relationship with sworn sisters hurt beyond reason. That she was suggesting that somehow we could still be friends literally took my breath away. To me, what she had written was ten thousand times worse than if my husband had walked in and announced he'd just taken his first concubine. (See 2005: 220)

For the women who were matched as laotongs, to be betrayed by their own 'old same' was far more severe and unforgivable than being betrayed by their husbands. The woman who betrayed her laotong would definitely be condemned both by her own laotong and by other women for her disloyalty. Thus, this relationship was regarded as most sacred and essential for women.

Apart from the emotional significance, the laotong relationship is employed to reinforce a girl's morality and the worth of a good marriage. Provided that two girls from different villages who are paired as laotongs are able to retain their good companionship, both of them will be allowed to marry into their village. This match is a tool to link two villages as well.

This laotong relationship will give her added value and show people in Tongkou that she is worthy of a good marriage into their village. And since the bond between two old sames is forever and does not change with marriage, ties with people in Tongkou will be further cemented and your husband — and 
all of us - further protected. (See 2005: 44)

Also, this type of female relationship can be interpreted as a remedy for isolation and melancholy resulting from being oppressed by patriarchy. The two women need to learn how to trust and how to support each other when one of them has to endure hardship. In Snow Flower and the Secret Fan, Lisa See points out that such a laotong relationship is a focal theme that inextricably links the fate of two female characters, Lily and Snow Flower. When Lily is about to become seven years old, she begins her so-called laotong relationship with a girl whose name is Snow Flower. These two girls learn how to support and help each other. Both of them initiate a relationship that is deeper and more lasting than an ordinary friendship. Lily decides to devote herself to her everlasting companionship with Snow Flower, as is shown in her speech "I loved Snow Flower. I would never hurt her by repeating Madame Gao's venomous remarks." (See 2005: 76)

Lily's intimate relationship with Snow Flower can be interpreted as a substitution for her mother's love that she has longed for. With disappointment and fury at her mother, Lily seeks for love from Snow Flower and she hopes that her laotong can bring her lost love back.

However, the relationship between two female characters is somewhat ambiguous and can be viewed as a homosexual romance. Most of the scenes that depict this type of relationship convey a sense of lesbianism. Readers will notice that Lily's affection for Snow Flower is much more intimate than any other friendship or with sworn sisters. Whenever Lily and Snow Flower spend time together, especially sleeping in the same bed at night, both of them express love by cuddling or touching the other's body, which could imply sexual intercourse. The romance between Lily and Snow Flower is linked to the soul rather than the physical body. The sense of homosexual romance is also portrayed in terms of metaphor 'a pair of mandarin ducks' which means 'lovers' and 'marriage' in Chinese culture, as shown in Snow Flower's message written on a fan.

I thought we would have our whole lives together. I never believed this day would come. It is sad that we came into this life wrong-as girls - but this is our fate. Lily, we have been like a pair of mandarin ducks. (See 2005:112)

What Snow Flower writes to Lily reflects her homoerotic relationship with her laotong in the form of a message. Moreover, in expressing sexual desire, Lily and Snow Flower learn to use Nü Shu, as a tool to avoid being gazed at by the society. This suggests how the female characters adapt for survival in a heterosexual society.

I was eager for her to experience what I had felt. [...] I chose the spot that had been most exquisite for me [...]. I wrote the character, which can mean bending over, kowtowing, or prostrating oneself. On her other ankle I traced the word I. I set her feet down and wrote a character on 
her calf. After this, I moved to a spot on the inside of her left thigh just above her knee.

(See 2005: 87)

However, the eternal relationship between Lily and Snow Flower is shattered because of Lily's misreading. After reading Snow Flower's message, Lily mistakenly believes Snow Flower has been unfaithful to her and shared her love with other women. Lily feels disappointed and infuriated with Snow Flower. She condemns Snow Flower's betrayal in front of others. For this issue, I argue that the conflict between Lily and Snow Flower is implicitly plotted by the author because this conflict reflects the anxiety and fear of a heterosexual Chinese society for a laotong relationship.

Such homoerotic relationships between women are viewed as a threat to the family institution which focuses on production and child-bearing. The laotong relationship also undermines male authority, especially husbands, because this type of relationship is reserved for only women and ignores male existence. In Snow Flower and the Secret Fan, Lily tells readers that she and Snow Flower are allowed to share a bed at any time without their husbands 'objection.

We shared a bed in each other's homes, while our husbands moved to other rooms to allow us time together. The butcher dared not object, following my husband's lead in this regard. But how could they have stopped any of it-our visits, our nights together, our whispered confidences? (See 2005: 216)

I also argue that the dispute between the two female characters, brought about by Lily's misreading, is a means for restoring heterosexual Chinese norms and restoring male authority after such sexual ambivalence. The demise of Snow Flower is an apparent assertion of heterosexual normalcy bringing it back to the patriarchal Chinese society.

\section{Conclusion}

Snow Flower and the Secret Fan by Lisa See depicts the lives of Chinese women in the Late Qing Dynasty through the two female characters; Lily and Snow Flower. Through the images of Chinese women presented in this novel the author explores the Western erotic fantasy about fascinating China. In the novel, readers can see how 'space' is linked to 'women's identity', including the activities involved. Lisa See also illustrates how discursive practice exercises Chinese women's bodies in terms of foot-binding. However, the female characters show readers how to adapt themselves and come to terms with such corporeal mutilation. Moreover, Lisa See valorizes the relationships between two women in 'laotong'. It is regarded as an 'emotional marriage' which enables women to survive in patriarchal society. Meanwhile, this kind of relationship is ambivalent and seems like a homosexual romance. Snow Flower and the Secret Fan reveals how Chinese women attempt to express their feelings and desires. To unearth the silenced voice, Chinese women invented 'Nü Shu' a female 
language adapted from official Chinese. This language is also used to record women's stories that have been overlooked by official history.

\section{References}

Archer, John. 2005. Architecture and Suburbia: From English Villa to American Dream House, 1690 -2000. Minneapolis, London: University of Minnesota Press.

Abudi, Dalya. 2011. Mothers and Daughters in Arab Women's Literature: The Family Frontier. Leiden and Boston: Brill.

Brownell, Susan and Wasserstrom, N. Jeffrey. 2002. Chinese Femininities and Chinese Masculinities. London: University of California Press.

Davis, Z., Sarah. 2009. The Friends We Keep: A Woman's Quest for the Soul of Friendship. New York: WaterBrook Press.

Dorothy, Ko. 1997. The Body as Attire: The Shifting Meanings of Foot-binding in Seventeenth-Century China. Journal of Women's History, Vol.8 No.4: 8-27.

Felski, Rita. 2000. Doing Time: Feminist Theory and Postmodern Culture. New York and London: New York University Press.

Jenkins, Keith. 1997. The Postmodern History Reader. London, New York: Routledge.
Highmore, Ben. 2002. Everyday Life and Cultural Theory: An Introduction. London, New York: Routledge.

Lee, Lin-Lee. 2002. Creating a female language symbolic transformation embedded in Nu Shu. In Chinese communication studies: Contexts and comparisons, edited by X. Lu, W. Jia, \& R. Heisey. Westport: Greenwood Publishing Group.

Li Yun Ning. 2015. Chinese Women Through Chinese Eyes. London and New York: Routledge.

Lisahunter, Wayne Smith and Elke Emerald. 2015. Pierre Bourdieu and Physical Culture. London and New York: Routledge.

Mann, Bonnie. 2014. Sovereign Masculinity: Gender Lessons from the War on Terror. New York: Oxford University Press.

McLaren, A., Margaret. 2002. Feminism, Foucault, and Embodied Subjectivity. Albany: State University of New York Press.

Rabaté, Jean - Michel. 2003. The Cambridge Companion to Lacan. Cambridge: Cambridge University Press.

See, Lisa. 2005. Snow Flower and the Secret Fan. New York: Random House, Inc. 
Adorned Body, Female Language, and Emotional Marriage between Chinese Women in Snow Flower and The Secret Fan

Warhol, R. Robyn and Herndl, P. Diane.

1997. Feminisms: An Anthology of

Literary Theory and Criticism. New

Brunswick: Rutgers University Press. 